\title{
Stac gets the skeletal L-type calcium channel unstuck
}

Commentary

\author{
Norbert Weiss
}

Institute of Organic Chemistry and Biochemistry, Academy of Sciences of the Czech Republic, v.v.i., Prague, Czech Republic

Commentary to: Stac adaptor proteins regulate trafficking and function of muscle and neuronal L-type $\mathrm{Ca}^{2+}$ channels. (Proc. Natl. Acad. Sci. 2015, pp. 602-606)

Key words: Calcium channel $-\mathrm{L}$-type calcium channel $-\mathrm{Ca}_{\mathrm{v}} 1.1$ channel $-\mathrm{Stac}$ adaptor protein - Excitation-contraction coupling — Trafficking

In mammalian skeletal muscle, contraction is triggered by the excitation-contraction (E-C) coupling machinery localized at the triad, a specialized membrane structure formed by the juxtaposition of T-tubules and sarcoplasmic reticulum (SR) cisternae. E-C coupling relies on a tight control of SR $\mathrm{Ca}^{2+}$ release through the type-1 ryanodine receptor (RyR1) by the voltage-gated $\mathrm{Ca}_{\mathrm{v}} 1.1 \mathrm{Ca}^{2+}$ channel (the so-called dihydropyridine receptor or DHPR) via a mechanical coupling of $\mathrm{Ca}_{\mathrm{v}} 1.1$ / RyR1 channels. Activation of the $\mathrm{Ca}_{\mathrm{v}} 1.1$ channel in response to transverse (T-) tubule membrane depolarization directly activate RyR1, allowing rapid rise in myoplasmic $\mathrm{Ca}^{2+}$ concentration via mobilization of the $\mathrm{SR} \mathrm{Ca}{ }^{2+}$ store, that in turn triggers muscle contraction (Calderon et al. 2014). In addition, the DHPR also play an essential role in the control of RyR1 gating in resting skeletal muscle (Robin and Allard 2012). Hence, precise trafficking and regulation of $\mathrm{Ca}_{\mathrm{v}} 1.1$ channels at the cell surface is essential for proper muscle function. Surprisingly, while nine out of the ten voltage-gated calcium channel members including both high-voltage-activated and low-voltage-activated channels have been successfully expressed in non-native systems (either in mammalian or non-mammalian cell types), $\mathrm{Ca}_{\mathrm{v}} 1.1$ has remained the only channel subtype to present either weak or total absence of functional expression in cells that are not of muscle origin. It is well known that ancillary subunits of voltage-gated $\mathrm{Ca}^{2+}$ channels (VGCCs), especially the $\mathrm{Ca}_{\mathrm{v}} \beta$ subunit, play an essential role in the trafficking of the $\mathrm{Ca}_{\mathrm{v}}$ pore-forming subunit of high-voltage-gated channels to the cell surface, possibly by masking an ER retention signal present in the $\mathrm{Ca}_{\mathrm{v}}$-subunit (Bichet et al. 2000). In contrast,

Correspondence to: Norbert Weiss, Institute of Organic Chemistry and Biochemistry, Academy of Sciences of the Czech Republic, v.vi.i., Flemingovo nám. 2, 16610 Prague 6 - Dejvice, Czech Republic E-mail: weiss@uochb.cas.cz while $\mathrm{Ca}_{\mathrm{v}} \beta$ functionally modulates $\mathrm{Ca}_{\mathrm{v}} 1.1$ channel expressed in muscle cells, co-expression of $\mathrm{Ca}_{\mathrm{v}} \beta$ in non-muscle environment is not sufficient for functional surface expression of the channel, suggesting an additional ER retention mechanism specific for $\mathrm{Ca}_{\mathrm{v}} 1.1$ channel. An interesting new study by Polster and colleagues (Polster et al. 2015), reported in a recent issue of the Proceedings of the National Academy of Science of the United States of America, reveals a key role of Stac adaptor proteins in the cellular trafficking of the skeletal L-type channel, and providing for the first time the molecular conditions for proper functional expression of the channel in non-muscle environment.

Stac proteins (SH3 and cysteine-rich-containing proteins) form a family of adaptor proteins (i.e. proteins which facilitate interactions between protein-binding partners and the generation of bigger signaling complexes) of three members (Stac1 to Stac3). While Stac2 is best known for its neuronal expression pattern, Stac3 is essentially expressed in skeletal muscle where it localizes at triad junctions with the $\mathrm{Ca}_{\mathrm{v}} 1.1$ channel (Nelson et al. 2013). In addition, knockdown of Stac3 in both mammalian and fish skeletal muscles alter E-C coupling (Horstick et al. 2013; Nelson et al. 2013) and myotube formation and myogenic differentiation (Bower et al. 2012). However, the cellular and molecular mechanisms by which Stac 3 contributes to proper E-C coupling remain incompletely understood. Polster and colleagues used a combination of confocal imaging microscopy and electrophysiological recording from non-muscle and muscle cells in vitro to test the hypothesis that Stac3 may contribute to the proper trafficking of $\mathrm{Ca}_{\mathrm{v}} 1.1$ to the cell surface. These authors found that while $\mathrm{Ca}_{\mathrm{v}} 1.1$ expressed alone in non-muscle tsA201 cells is essentially retained in the SR, coexpression of Stac3 triggers efficient trafficking of the channel to the plasma membrane where both proteins colocalize. In addition, electrophysiological recordings indicate that the $\mathrm{Ca}_{\mathrm{v}} 1.1$ channel 
is not only expressed at the cell surface, but is also fully functional and presents similar biophysical characteristics as when expressed in muscle cell environment. This paper also shows that expression of Stac3 at the triad is independent of the presence of RyR1. Indeed, while a punctate distribution of Stac 3 consistent with a targeting to plasma membrane/SR junctions is observed in dyspedic myotube (RyR1 null), expression of Stac 3 in dysgenic myotube $\left(\mathrm{Ca}_{\mathrm{v}} 1.1\right.$ null $)$ remains diffuse. Altogether, these data imply that binding of Stac3 to $\mathrm{Ca}_{\mathrm{v}} 1.1$ channel is likely required for the proper delivery of the channel to the plasma membrane/SR junctions. Finally, Polster and colleagues showed that Stac proteins, although not essential for efficient cell surface delivery of the closely related cardiac/neuronal $\mathrm{Ca}_{\mathrm{v}} 1.2$ channel (Lichvarova and Lacinova 2015), colocalize and produce a potent modulation of the channel gating.

The novel and important findings of Polster and colleagues provide a compelling response to the long-standing enigmatic absence of functional expression of $\mathrm{Ca}_{\mathrm{v}} 1.1$ channel in non-muscle cells. It also provides an effective tool that will allow further analysis of the regulation and pharmacology of the $\mathrm{Ca}_{\mathrm{v}} 1.1$ channel, but also the functional characterization of pathological mutations on the channel gating in a simple cellular system. This paper also highlights a striking difference in the way Stac proteins modulate surface trafficking and function of two closely related channels. Whether or not Stac3 also modulates the gating of $\mathrm{Ca}_{\mathrm{v}} 1.1$ similarly to $\mathrm{Ca}_{\mathrm{v}} 1.2$ remains difficult to investigate because of the essential role of Stac3 in the functional delivery of the channel to the plasma membrane. This aspect can nonetheless be investigated using small interfering peptides to biochemically uncouple $\mathrm{Ca}_{\mathrm{v}} 1.1$ from Stac3 in skeletal muscle cells where the channel is already present at the cell surface. The DHPR-dependent $\mathrm{Ca}^{2+}$ current was suggested to play a role in the aggregation of acetycholine receptors during postsynaptic development (Milholland et al. 2007) and in the fusion of satellite cells (Luin and Ruzzier 2007). More interestingly, it was also proposed to contribute to maintaining $\mathrm{Ca}^{2+}$ transients in response to prolonged depolarizations or repeat trains of action potentials (Gach et al. 2008). Hence, the findings of Polster and colleagues raise the interesting possibility that Stac3, by modulating the gating of $\mathrm{Ca}_{\mathrm{v}} 1.1$ channels, may
A

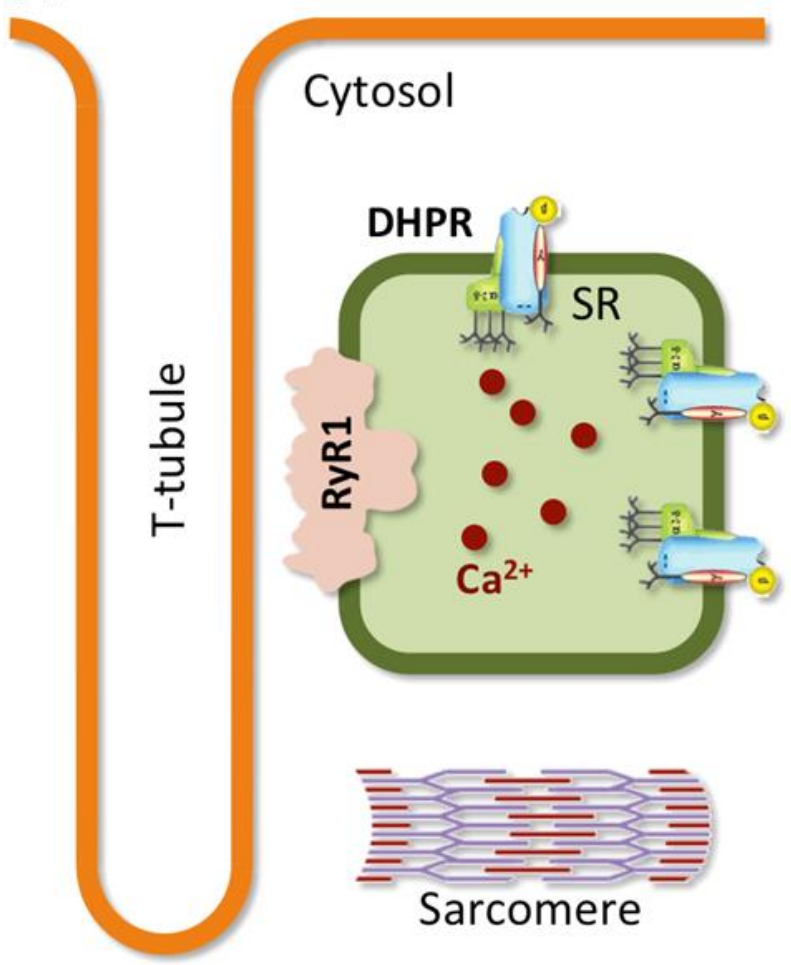

B

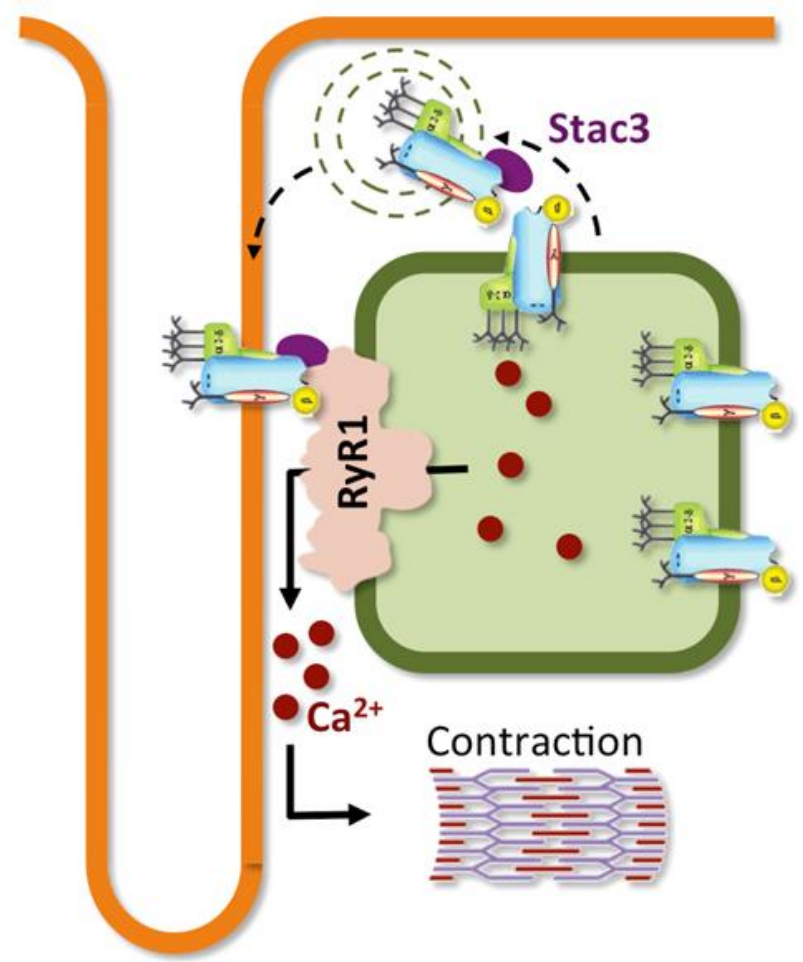

Figure 1. Schematic representation of the regulation of $\mathrm{Ca}_{\mathrm{v}} 1.1$ channel by Stac3 in skeletal muscle. A. In the absence of $\mathrm{Stac}, \mathrm{Ca}_{\mathrm{v}} 1.1-$ containing DHPR does not traffic to the cell surface and is retained in the SR, possibly via an SR retention motif in the Ca 1.1 -subunit. B. The presence of Stac3 triggers $\mathrm{Ca}_{\mathrm{v}} 1$ 1.1-containing DHPR to exit the SR and traffic to the plasma membrane / SR junctions where it forms a biochemical complex with RyR1, allowing $\mathrm{Ca}^{2+}$ release from SR store upon membrane depolarization and sarcomere contraction. Stac3, stac adaptor protein 3; SR, sarcoplasmic reticulum; DHPR, dihydropyridine receptor; RyR1, ryanodine receptor type-1. 
have a broader implication in muscle physiology. Finally, acute biochemical uncoupling of $\mathrm{Ca}_{\mathrm{v}} 1.1 / \mathrm{Stac} 3$ complexes in fully differentiated muscle cells (Lefebvre et al. 2014) will also provide essential information on the role of Stac3 in E-C coupling independently of its chaperone role in the surface trafficking of the channel.

Overall, the findings of Polster and colleagues provide novel insights into the molecular physiology of the skeletal muscle, and establish Stac3 adaptor protein as a key player in regulating $\mathrm{Ca}_{\mathrm{v}} 1.1$ surface expression and thus E-C coupling.

Acknowledgement. Work in the Weiss laboratory is supported by the Czech Science Foundation, the Czech Ministry of Education Youth and Sports, and the Institute of Organic Chemistry and Biochemistry.

\section{References}

Bichet D., Cornet V., Geib S., Carlier E., Volsen S., Hoshi T., Mori Y., De Waard M. (2000): The I-II loop of the Ca2+ channel alpha1 subunit contains an endoplasmic reticulum retention signal antagonized by the beta subunit. Neuron 25, 177-190 http://dx.doi.org/10.1016/S0896-6273(00)80881-8

Bower N. I., de la Serrana D. G., Cole N. J., Hollway G. E., Lee H. T., Assinder S., Johnston I. A. (2012): Stac3 is required for myotube formation and myogenic differentiation in vertebrate skeletal muscle. J. Biol. Chem. 287, 43936-43949 http://dx.doi.org/10.1074/jbc.M112.361311

Calderon J. C., Bolanos P., Caputo C. (2014): The excitationcontraction coupling mechanism in skeletal muscle. Biophys. Rev. 6, 133-160 http://dx.doi.org/10.1007/s12551-013-0135-x

Gach M. P., Cherednichenko G., Haarmann C., Lopez J. R., Beam K. G., Pessah I. N., Franzini-Armstrong C., Allen P. D. (2008): Alpha2delta1 dihydropyridine receptor subunit is a critical element for excitation-coupled calcium entry but not for formation of tetrads in skeletal myotubes. Biophys. J. 94, 3023-3034

http://dx.doi.org/10.1529/biophysj.107.118893

Horstick E. J., Linsley J. W., Dowling J. J., Hauser M. A., McDonald K. K., Ashley-Koch A., Saint-Amant L., Satish A., Cui W. W., Zhou W. et al. (2013): Stac3 is a component of the excitationcontraction coupling machinery and mutated in Native American myopathy. Nat. Commun. 4, 1952

http://dx.doi.org/10.1038/ncomms2952

Lefebvre R., Pouvreau S., Collet C., Allard B., Jacquemond V. (2014): Whole-cell voltage clamp on skeletal muscle fibers with the silicone-clamp technique. Methods Mol. Biol. 1183, 159-170 http://dx.doi.org/10.1007/978-1-4939-1096-0_9

Lichvarova L., Lacinova L. (2015): CaV1.2 and CaV1.3 L-type calcium channels regulate the resting membrane potential but not the expression of calcium transporters in differentiated PC12 cells. Gen. Physiol. Biophys. 34, 157-165

Luin E., Ruzzier F. (2007): The role of L- and T-type Ca2+ currents during the in vitro aging of murine myogenic (i28) cells in culture. Cell Calcium 41, 479-489 http://dx.doi.org/10.1016/j.ceca.2006.09.006

Milholland R. B., Dulla C., Gordon H. (2007): L-type calcium channels mediate acetylcholine receptor aggregation on cultured muscle. Dev. Neurobiol. 67, 987-998 http://dx.doi.org/10.1002/dneu.20397

Nelson B. R., Wu F., Liu Y., Anderson D. M., McAnally J., Lin W., Cannon S. C., Bassel-Duby R., Olson E. N. (2013): Skeletal muscle-specific T-tubule protein STAC3 mediates voltageinduced $\mathrm{Ca} 2+$ release and contractility. Proc. Natl. Acad. Sci. USA 110, 11881-11886 http://dx.doi.org/10.1073/pnas.1310571110

Polster A., Perni S., Bichraoui H., Beam K. G. (2015): Stac adaptor proteins regulate trafficking and function of muscle and neuronal L-type Ca2+ channels. Proc. Natl. Acad. Sci. USA 112, 602-606 http://dx.doi.org/10.1073/pnas.1423113112

Robin G., Allard B. (2012): Dihydropyridine receptors actively control gating of ryanodine receptors in resting mouse skeletal muscle fibres. J. Physiol. 590, 6027-6036 http://dx.doi.org/10.1113/jphysiol.2012.237321 